\title{
TAX OPTIMIZATION AS A DECISIVE FACTOR OF ECONOMIC DEVELOPMENT (THE CASE OF POLAND)
}

\author{
Mykola ANDRIYASH ${ }^{1}$, \\ Institute of International Relations of Taras Shevchenko National University of Kyiv, Ukraine
}

\begin{abstract}
The main purpose of the paper is to compare the system of taxation and tax optimization in Poland with solutions in the selected EU Member States and its influence on economic development. The paper presents the system of taxation in Poland compared with fiscal solutions in selected EU countries. It also discusses the typology of tax solutions referring to tax optimization in Europe. Methodology. The author used the primary and secondary data from the Central Statistics Office (GUS), Pricewaterhouse Coopers' research and the Eurostat. The research methods used for the purpose of data analysis included economic analysis of legal acts, descriptive statistics, and comparative analysis. Results showed that the level of tax loading in Poland is more moderate than in other developed countries of the world while the mechanism of administration of taxes and collections is much more successful. The share of receipts collected by the decentralized administration has been increasing steadily since the major administrative reform of 1999 and the local finance law enacted in 2004. Eliminating the category of special sections of industrial production and inclusion of revenues/income to the proposed form of income tax would be very desirable. This would indicate the practical implementation of Smith's tax principles concerning tax equity and an ability of taxpayer to pay levies. Practical implications. Tax optimization is to balance the tax loading level through offering benefits and preferences which would stimulate the economy of the country and will not cause aggravation of the problem of relocating tax loading from one tax payer to another. Many national states, noticing the phenomena of tax evasion and tax avoidance are implementing or going to implement specific reforms which help to improve the system of tax control with the aim of creating conditions which make tax and collections evasion impossible. Value/originality. The results of the conducted research form the basis for drawing synthetic conclusions and making recommendations not only for Poland as for developing countries. Determining the most appropriate composition of government tax reforms in aspect of optimization remains an interesting issue for further research.
\end{abstract}

Key words: tax optimization, tax loading, economic activity, tax coefficient, effective tax rate, economic entity, financial provision, tax evasion.

JEL Classification: E62, H21, H22, H26

\section{Introduction}

The system of taxation and tax burden significantly affects the performance efficiency of all economic entities without exception. The influence becomes even more important with activation of innovative processes. Economic support of innovations and their implementations into production is one of the most critical factors for increasing innovation activity at the enterprise which, in its turn, defines a longterm economic competitiveness. However, such support should exist not only in the context of intra-corporate mechanisms but at the governmental level as well. An important area of institutional support of innovativeinvestment process is tax system improvement. The level of the tax burden is defined by the ratio of total tax payments (excluding individual income tax) to gross value added (Titov, Gigul'skiy, 2013). It is notable that one of the lowest rates in this regard in Europe is in Poland, one of the few countries which successfully and without serious consequences managed to overcome the hardest financial crisis in 2007-2009 and was not severely affected by the sovereign debt crisis in 2010-2011.

Thus, one of the main objectives of this paper is to perform economic analysis of tax optimization process under conditions of crisis and economic growth. An illustrative example in this regard is Poland.

The global financial crisis and concomitant economic slowdown has had a strong and negative impact on public finances in Poland. This effect was magnified by numerous tax cuts introduced in Poland in the years 2007-2009, which were not matched by the equivalent reduction in expenditures. As a result, both general government deficit and debt widened substantially. According to

\footnotetext{
Corresponding author:

${ }^{1}$ Department of World Economy and International Economic Relations, Institute of International Relations

of Taras Shevchenko National University of Kyiv.

E-mail: andrijashko@ukr.net
} 
the estimates presented by the Central Statistical Office (GUS 2012), in 2011 the general government deficit, measured in ESA-95 standards, reached a level of 5.1\% of GDP (as compared with $7.8 \%$ in 2010) and the debtto-GDP ratio stood at $56.3 \%$ of GDP ( $54.8 \%$ in 2010 ). In order to mitigate the risk related to fast debt increase the government introduced a mixture of expenditure cuts and tax increases. These measures embraced inter alia introduction of an expenditure rule, changes in the funded defined contribution scheme (limiting transfers to open pension funds - OFE) and adjustment of indirect taxes (value added tax was raised from 2011 by 1 pp.). Since beginning of economic transformation the case for flat tax in Poland has been frequently made in the public debate (Boratyński, Borowski, 2012). Surprisingly little, however, has been said so far on the long-run macroeconomic effects of changing the tax regimes towards single PIT rate on the Polish economy. The empirical research on this topic barely exists and papers published so far addressed only the revenue effects of the tax reform (Neneman, Piwowarski, 2004).

The problem of tax optimization, the tax structure, the measurement of taxable basis (income, capital), and determining optimal (or sub-optimal) tax rate seems to be more important in the developed countries. Also, have been little explored tax concessions lead to implications for; inter alia, production, incomes, trade, rural society, and other economic categories (Soliwoda, PawlowskaTyszko, 2014).

The aim of this paper is an attempt to compare the system of taxation and tax optimization in Poland with solutions in the selected EU countries and its influence on economic development. The following research tasks are included: (i) analyzing the system of taxation in Poland, including proposals for its reform, and (ii) presenting the typology of tax solutions referring to optimization.

\section{The system of taxation in Poland}

Poland became the first state in the Eastern Europe which rejected communism and began to implement political and economic reforms not only actively but also successfully. In 1989 Poland faced two strategic tasks: membership in NATO and the European Union. To accomplish those tasks the country actively implemented social, economic and legal transformations which allowed us to call Poland a "European tiger".

Nevertheless, the development of Polish state does have its political and legal drawbacks and economic errors. As we all know, you do not make mistakes, if you do not work, but today the mistakes of Polish government are mirrored in the recession of economic reforms, increase of the budgetary deficit and in economic stagnation, in general. On the background of these processes, the tax system in Poland serves as a safety ring (European Commission, 2014).

On referendum 1997 a new Polish Constitution was adopted (and later approved by the Polish National Assembly). According to the Polish Constitution taxes can be imposed only as provided for by law and cannot be unreasonably high. However until now the level of taxation in Poland is still relatively high and it concerns both individuals and entities. There are grounds for it as the main sources for reinforcing the budget of Poland are: (1) indirect taxes (including, VAT and excise taxes); (2) tax payments from enterprises; (3) tax payments from individuals. Other charges and payments do not significantly affect the budget. However today, Poland integration into consolidated European fiscal space objectively requires serious tax reforms and adaptation of the tax system to the norms of European legislation (Table 1). The period for tax transformations today does not depend on the expectations of Polish authorities and the first steps in this direction have already been made (Bartosik, 2012).

In Poland there is a two-level taxation system consisting of governmental taxes payable to the federal budget and local taxes payable to local budgets. According to the general rule, entities and individuals who are not the residents of Poland, are subject to taxes equally as the residents of Poland unless otherwise is provided in international agreements ratified by Poland.

The main taxes in Poland are profit tax, income tax, value added tax, excise tax (Fig. 1). Entities conducting their

Table 1

\section{Overview of last tax reforms in Poland}

\begin{tabular}{|l|l|}
\hline \multicolumn{1}{|c|}{ Corporate income tax } & $\begin{array}{l}\text { The corporate tax was extended to cover certain types of partnerships which had previously been } \\
\text { used for tax avoidance purposes. }\end{array}$ \\
\hline VAT & $\begin{array}{l}\text { The temporary increase in the standard VAT rate was extended for another three-year period } \\
\text { (until the end of 2016). }\end{array}$ \\
\hline $\begin{array}{l}\text { Excise duties and other taxes on energy } \\
\text { products and electricity }\end{array}$ & Excise duty on natural gas for heating was introduced, with effect from November 2013. \\
\hline Excise duties on alcohol and tobacco & Excise duties on tobacco products were increased by $5 \%$ and duties on alcohol by $15 \%$. \\
\hline Other measures & $\begin{array}{l}\text { In April 2015, the government presented a package of further reforms designed to improve both tax } \\
\text { compliance and the efficiency of tax and customs administration. A consolidation of organizational } \\
\text { functions within the tax administration has been announced. A single database of tax identification } \\
\text { numbers was introduced to replace the local databases managed by the tax offices. }\end{array}$ \\
\hline
\end{tabular}

Source: (Tax reforms in EU Member States / Publications Office of the European Union - 2014 report) 
business on the territory of Poland or raising revenues on its territory must be registered in appropriate tax authority and obtain identification tax number.

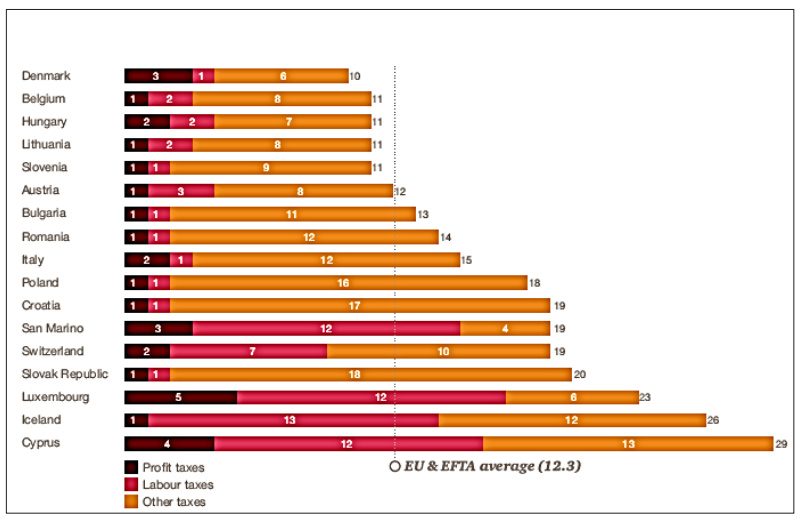

Fig. 1. EU \& EFTA (Number of tax payments)

Source: (PricewaterhouseCoopers' research / The World Bank and International Finance Corporation - Paying Taxes 2015-2014 edition)

Tax administration system in Poland has several levels: (1) local tax authorities/ regulatory tax authorities which control tax payments on their territory and are authorized to accept individual administrative acts (explanatory statements) regarding taxpayers applications. However these statements are only of recommended nature; (2) tax chambers controlling tax authorities and they are authorized to review decisions adopted by these authorities (Raczkowski, 2015); (3) Ministry of Finances controlling the state of tax system in Poland in general and it has authority to give official interpretation of tax legislation.

\section{Overall trends in tax optimization}

In Poland the overall tax burden in 2012 remained close to 2011 level at $32.5 \%$ of GDP (increase of $0.2 \%$ ), and remained nearly 7 percentage points below the EU-28 weighted average (39.4\%). Among neighbouring countries, this value is higher than in Slovakia (28.3\%), but lower than the tax-to-GDP ratios in the Czech Republic (35\%), Hungary (39.2\%) and Germany (39.1\%).

Indirect taxes (13.1\% of GDP) accounted for $40.4 \%$ of total tax receipts and continue to play a more important role than direct taxes, which in 2012 raised $22.3 \%$ of total tax revenues. This trend goes against the EU-28 trend where indirect and direct taxes make up respectively $34.5 \%$ and $33.4 \%$ of total taxes. However, the trend could be at a turning point as, in 2012, the indirect tax share dropped by nearly $3 \%$ compared to 2011 , whilst the share of direct tax rose nearly by $1 \%$. Social contributions ( $12.3 \%$ of GDP) accounted for well over a third of total tax revenues in 2012 (37.7\%), which is 5.4 percentage points above the EU-27 average (32.4\%) (Eurostat Statistical books, 2014).

The share of receipts is collected by the decentralized administration has been increasing steadily since the major administrative reform of 1999 and the local finance law enacted in 2004 (9.1\% in 1999). It has remained stable since 2007 , oscillating around $13 \%$ (12.7\% in 2012$)$. The allocation to the central government $(49.2 \%$ in 2012$)$ has also remained stable in the period under consideration. The share accruing to social security funds stopped a downward trend in 2011, when it stood at $35.0 \%$ and increased to $37.4 \%$ in 2012 .

The overall tax burden decreased progressively from $37.1 \%$ of GDP in 1995 to $31.5 \%$ in 2004, reflecting mostly the reduction of statutory tax rates. In contrast, the 200507 period was characterized by an increase in the tax-toGDP ratio, which reached a level of $34.8 \%$ in 2007 . This strong upward trend was driven mostly by an increase of VAT revenues as a result of a strong domestic consumption, and by robust growth of PIT revenue due to the rise of employment. The tax-to-GDP ratio has decreased between 2008 and 2009, mostly due to the changes in PIT which implied a net loss of the budget revenue coming from direct taxes. Over the last three years the tax-to-GDP ratio slightly increased from $31.8 \%$ in $2009-10$ through $32.3 \%$ in 2011 to $32.5 \%$ in 2012, perhaps in relation to the increase by 1 percentage point of statutory VAT rates that occurred in 2011 . Indeed VAT revenues increased by $11.8 \%$ in 2011 (and by $10.2 \%$ in 2010 ), while they dropped by $5.1 \%$ in 2012 comparing to 2011 . Moreover, the VAT revenue to GDP ratio decreased from $8.0 \%$ in 2011 to $7.3 \%$ in 2012 (European Commission, 2014).

The consumption taxes in Poland mirror the EU trend; after their 2009 slight decrease to $11.7 \%$ of GDP they bounced back in 2010 to the level of $12.5 \%$ of GDP and continued to rise to $12.6 \%$ in 2011 . However, in 2012 the index of consumption taxes decreased to $11.8 \%$ of GDP (whereas the EU-28 weighted average remained stable in 2011 and 2012 at the level of $11.2 \%$ ). This is reflected as well in the corresponding ITR, which stood at $19.3 \%$ in 2009 (lowest since 2004), but bounced back to $20.5 \%$ in 2010 and $20.8 \%$ in 2011, as did the EU average (at $19.7 \%$ in 2010 and $19.9 \%$ in 2011). The ITR on consumption, on a declining trend from 1995 to 2001, picked up since as a result of a strong VAT and excise duties revenue growth after the introduction of excise duties on energy, increased VAT rates on certain items in 2002, increase of the statutory VAT rates by 1 percentage point in 2011, broadening of the VAT base, and in the aftermath of Poland's accession to the EU. The decrease in 2009 was most likely caused by lower consumption levels triggered by the economic downturn and lowering receipts from the VAT and excise but also change to the structure of VAT receipts (shift towards goods and services taxed at a preferential rate). The 2010 and 2011 recovery, common for most EU countries, was most likely caused by the growing market confidence and a temporary increase of statutory VAT rates by 1 percentage point that has started since 2011 and was meant to end in 2013 (but instead was prolonged for another three-year period of 2014-16). It appears that this fuelling of VAT revenues has reached its potential, however, in 2012. 
Taxes on labour, amounting to $13.1 \%$ of GDP, are the seven lowest in the EU (the EU-28 average 20.1\%). In fact, over the last 16 years Poland has experienced a significant tax shift away from labour taxation (-3.9 percentage points). The ITR on labour has been steadily decreasing since its 10 -year peak in 2006 (35.4\%), to climb to $32.0 \%$ in 2011 and to $33.9 \%$ in 2012, 2.2 percentage points below the EU-28 weighted average (36.1\%). Tax wedge on labour (on 100\% average wage of a single person without children) amounted in 2012 to $35.5 \%$ a $1.1 \%$ increase comparing to $201134.3 \%$ of labour cost — but still the seven lowest in EU. It is also the lowest tax wedge in the region, where the neighbouring countries such as Slovakia (39.6\%), Czech Republic (42.4\%) Hungary (49.4\%) and Germany (49.7\%) all impose higher burdens on labour (The World Bank and International Finance Corporation, 2014).

In August 2010 the Polish government adopted a Multiannual Financial Plan proposing increase in indirect taxes (about $0.4 \%$ of the GDP). A series of measures in the VAT area came into force in 2011, of which the most important is the temporary increase (for the years 201113 ) of the VAT rates by 1 percentage point, from $7 \%$ to $8 \%$, and from $22 \%$ to $23 \%$. In 2013 these temporary increased rates were extended for the period 2014-16. At the same time, a new reduced rate of $5 \%$ has been introduced for, amongst others, basic foodstuff. Moreover, as of 2012 the VAT rates for certain products, including medical devices, clothing and clothing accessories for infants and children's footwear, increased from $8 \%$ to $23 \%$. From 2013, the $23 \%$ rate is due to apply for arts and crafts and on non-public postal services.

The government increases gradually the excise duties rates on tobacco products (by $4 \%$ a year) but also for fuels (jet engine fuels, diesel and intrinsic bio-components). Excise duties on car fuel remained untouched over period 2007-11, but in 2012 the excise on diesel has increased substantially. In line with the Energy Directive, as of 2012 the excise tax is also applicable to coal, lignite and coke, so far exempted.

In May 2010 Poland's government introduced reforms to the pension system scheme when transfers to privately managed pension funds were cut from $7.3 \%$ to $2.3 \%$ of workers' salaries and the $5 \%$ difference was redirected into the public old-age pension system (Kryńska, 2014). The law on pension funds was amended again in December 2013 with effect from 1 February 2014 to slightly increase the pension fund contribution up to $2.93 \%$ of a salary. Based on this law all present members of the privately managed pension funds will have the right to abandon the pension fund and choose the state social security scheme instead (the first choice will have to be made between April and July 2014 and then every two years). Depending on this choice further decrease in contributions for privately managed pension funds may occur as only contributions of those members who will stay within the fund system will be transferred to funds. Moreover, based on this law privately managed pension funds will have to transfer about half of their assets, composed of government bonds, to the public old-age pension system where the bonds will be redeemed. Resulting transfers have been estimated at approx. EUR 37.5 billion (circa 7\% of GDP).

\section{Methods of tax optimization evaluation at enterprise level}

Any corporate tax optimization bears some risk. Moreover its implementation requires expenses, that is why it is necessary to conduct a detailed analysis before optimization to define if the costs and the risk worth it.

Tax planning and its efficiency should be placed against the tax burden of the enterprise. If the latter against the company revenue does not exceed $10 \%$, then further measures to reduce taxes are going to be senseless. If this figure is over $60 \%$, tax planning is always inefficient as this figure requires the change of business activity or tax jurisdiction (Nickel, Vansteenkiste, 2008).

The basic criterion of optimization is traditionally considered as a balance between economy from the taxes and costs for implementing tax optimization schemes. Simple and easy to use criteria, it can be calculated as at the stage of tax planning and using factual data. Its analysis gives the answer to the question if the proposed method of optimization is reasonable. However despite relative character of these criteria and its evident advantages, it has a number of drawbacks.

The researcher Anna Bobrova (2014) developed a universal criteria for tax optimization taking into account not only costs for developing and maintaining the optimization scheme of a certain tax and the total savings but also the following factors: type of a taxpayer (1); tax share in a taxpayer's tax burden (2); interest degree of tax authorities in this tax (3); legislative complexity of the tax (4); duration of optimization scheme (5).

The factors 1 and 2 are interrelated as the organizational structure of a company defines the standard structure of a tax burden of a taxpayer. Using a general calculation formula, it is possible to take into account the structure of a tax burden for each individual taxpayer. Dependence of optimization criteria on the tax share in a taxpayer tax burden is linearly proportional: the higher amount to be paid, the greater relative economy.

The factor of tax authority's interest should be taken into account as the border between optimization and tax avoidance shifts towards tax legislation breach. The bigger share for budget revenue provides a certain tax resource, the higher probability that this tax will generate a great interest among tax authorities. Consequently, factor 3 can be expressed by means of a tax share in budget tax revenue. Dependence of a universal criterium for tax optimization on the factor 3 is inversely proportional: the greater attention of tax authorities (the larger tax share in the budget), the less will be the economy (Bobrova, 2014).

Legislation complexity of the tax also reflects optimization capabilities. Complex branch multi-step 
schemes for building a number of taxes provide multiple precedents for optimization. The number of tax regulations is so simple and laconic that they do not allow any other effective ways for their optimization. The more complex the tax, the easier it is to find optimization conditions for it and even the lowest level of the economy will be considered a positive effect.

Taking into account everything that was said before, the formula for universal tax optimization criteria will be the following:

$$
\begin{aligned}
& U C e_{f}=\frac{E_{n}}{S_{m}} \times K_{2} \times K_{5} \div K_{3} \times K_{4} \\
& \text { where: }
\end{aligned}
$$

UCef - is universal tax optimization criteria;

- En - is economy from taxes in the result of optimization, in monetary units;

- Sm - are the costs for developing and maintaining optimization scheme, in monetary units;

$\mathrm{K} 2$ - is coefficient taking into account factor 1 or 2 .

In the final version of the formula the sign of optimization is taken into account. It is explained by the fact that during development of optimization schemes affecting a group of taxes, it is not always possible to reach a maximal reduction of all the constituting elements. Sometimes reduction of one group of taxes is accompanied by the growth of the other tax group. In this case, tax shares in a tax burden and in budget tax revenue should be calculated.

\section{Size and development of the shadow economy within Poland and of its neighbouring countries}

The average size of the shadow economy in 27 EU-Countries is $22.3 \%$ in 2003 and decreased to $18.4 \%$ (of official GDP) in 2013. The biggest ones are with 14.6\% unemployment and self-employment, followed by tax morale with $14.5 \%$ and GDP growth with $14.3 \%$. The size of tax evasion (accounting for indirect taxation and selfemployment activities) was on average $4.2 \%$ (of official GDP) in Poland, 1.9\% in Germany and 2.9\% in the Czech Republic (Schneider, Raczkowski, 2014).

Many national states, noticing the phenomena of tax evasion and tax avoidance are implementing or going to implement specific reforms, such as the following:

a) Bulgaria, 2012: Adopted a fiscal strategy to improve tax collection and control the avoidance of taxation;

b) Cyprus, December 2012: Allocated special funds for tax avoidance and financial abuse control in their successive budget for 2013. Imposed a number of obligations on both the business and the tax administration to improve information sharing and tighten tax regulations. Nonresidents are required to file annual tax returns and foundations are expected to account for dividends and interest;

c) Latvia: Adopted the so-called "zero declaration" for the legal notification of non-declared income to combat tax evasion and tax avoidance; d) Portugal, 2010: Adopted solutions enabling more control of tax evasion;

e) Estonia: Reinforced their controls against tax avoidance by controlled foreign companies (CFC), including specifically the restrictions on the use of transfer pricing systems;

f) UK: Seems to be the most successful and far going in its struggle against tax avoidance and evasion. Since 2010 they have earmarked almost 1 billion pounds for the control of tax abuses, tax avoidance (tax optimization) and tax evasion. They employed almost 2.5 thousand new employees at HMRC and allocated a special team of Offshore Co-ordination Unit to combat tax offenses in tax havens. They have provided for a possibility of publishing names of tax legislation abusers or offenders and established a penal tax rate of up to $200 \%$ against their tax evaders (Salo, 2013).

The size and development of the shadow economy of Poland it had a value of $27.7 \%$ in the year 2003, which then steadily declined to $25.3 \%$ in the year 2008 , increased slightly to $25.9 \%$ in the year 2009 and since then decreased to $23.8 \%$ for the year 2013. If we consider the direct neighbours of Poland, Germany, the Czech Republic, Slovakia and Lithuania, Germany had a shadow economy of $17.1 \%$ in the year 2003 which declined to $14.2 \%$ in the year 2008 and increased to $14.6 \%$ in 2009 and then decreased again to $13.0 \%$ in the year 2013. In the Czech Republic we had a shadow economy of $19.5 \%$ in 2003 which decreased to $16.6 \%$ in 2008 , increased to $16.9 \%$ in 2009 and decreased again to $15.5 \%$ in 2013. In Slovakia we had a shadow economy of $18.4 \%$ in 2003 which decreased to $16.0 \%$ in 2008 , increased to $16.8 \%$ in 2009 and decreased again to $15.0 \%$ in 2013. In Lithuania we had a shadow economy of $32.0 \%$ in 2003 which decreased to $29.1 \%$ in 2008 , increased to $29.6 \%$ in 2009 and decreased again to $28.0 \%$ in 2013 (Zucman, 2014).

What type of policy conclusions can we draw from these results?

- The reduction of the shadow economy can be achieved using various channels that governments can influence. The main challenge still is to bring shadow economy activities into the official economy in a way that goods and services previously produced in the shadow economy are still produced and provided in the official economy. Only then the government gets additional taxes and social security contributions and transfers value added from the shadow into the official economy;

- The main driving forces of the shadow economy are indirect taxes, followed by self-employment and unemployment. Hence, to reduce the shadow economy these are the most efficient policy options;

- It is essential to liquidate tax havens which are currently a tool for commercial and wholesale tax evasion through complicated structure of tax avoidance - which appears to be difficult in the medium term or even longterm - due to increasing number of beneficiaries who have the possibilities of hampering political and organizational precautious measures through their accumulation of the capital; 
- Fighting tax evasion from VAT-fraud is maybe the most important policy goal. If also in the European Union all member states try to efficiently fight tax fraud by making the VAT-system more efficient with clear-cut rules and little exemptions, then this would lead to great success in reducing this type of tax fraud. Due to the lack of the common fiscal policy it is unlikely to, among others, harmonize tax rates, and therefore the EU states having the highest tax rates should expect heightened risk of the tax reclaim fraud through numerous dummy transactions and buffer companies within intra-Community trade. Thus, it may lead to elimination of some honest business entities from the market which will be unable to compete with fraudulent entities in terms of the price. Budget losses triggered by the growing tax gap because of tax refunds undue will increase the deficit (and thus the public debt), and they may translate into spending cuts in the following tax year, which may impact the rate of economic growth.

\section{Conclusions}

Summarising the results of conducted investigation it should be noted that the level of tax loading in Poland is more moderate than in other developed countries of the world while the mechanism of administration of taxes and collections is much more successful. However, some scientists consider that a real level of tax loading is much higher and it has a bad influence on the economy of the country and causes social tension in the society. The problem of the equality and proportionality of the apportionment of tax pressure among tax payers is still unsolved.
The main task of officials, experts and scientists is to balance the tax loading level through offering benefits and preferences which would stimulate the economy of the country and will not cause aggravation of the problem of relocating tax loading from one tax payer to another. This problem can be solved by means of improving the mechanisms of tax administration since the expenses for the management of tax payments are not always grounded within the period they were spent. The solution as to the offering benefits should be taken on the account of the sphere of tax payer activity; i.e. the benefits should be given mainly to the investment and innovational enterprises to attract investors to concrete regions or branches of the economy which are not interesting for running entrepreneurial business under the regime of general system of taxation. It is necessary to emphasize that one of the most important ways of the optimization of tax pressure on payers is efficient policy of tax planning. It helps the economic entities to regulate the level of tax loading independently and legally by means of their own method of tax loading estimation and analysis of taxes which have to be paid.

The vital tasks on the way to the optimization of tax loading in Poland are the following:

- legislative improvement of the system of tax control with the aim of creating conditions which make tax and collections evasion impossible;

- regulation of taxation and accounting systems.

The tasks determine the urgency of the theme of investigation and emphasize the necessity of conducting further research in this direction.

\section{References}

Bartosik, K. (2012). Popytowe i podażowe uwarunkowania polskiego bezrobocia [Demand- and supply-side determinants of unemployment in Poland], Gospodarka Narodowa [National Economy], Szkoła Główna Handlowa [Warsaw School of Economics], Warsaw: p. 11-12.

Bobrova, A. (2014). Possibilities of optimization of taxes the enterprise on the basis of the international experience. Economics and Management - 3/2014: p. 203-221.

Boratyński, J., \& Borowski, J. (2012). The long-term economic impact of the flat tax in Poland. CGE simulation under alternative assumptions. Bank i Kredyt 43 (3), 2012: p. 5-30.

European Commission. (2014). Taxation trends in the European Union / [Data for the EU Member States, Iceland and Norway] // Eurostat Statistical books - 2014 edition - Taxation and Customs Union - Luxembourg: Publications Office of the European Union - 2014: p. 127-131.

European Commission. (2014). Tax reforms in EU Member States / Tax policy challenges for economic growth and fiscal sustainability - 2014 report - Luxembourg: Publications Office of the European Union - 2014: p. 1-147. Neneman, J., \& Piwowarski, R. (2004). Trzeci etap reform. Jaki system podatkowy, www.case.com.pl.

Kryńska, E. (2014). Labour Taxation In Poland Compared To The Other OECD Countries. Comparative Economic Research, Volume 17, Number 3, 2014: p. 47-62.

Nickel, C., \& Vansteenkiste I. (2008). Fiscal policies, the current account and Ricardian equivalence. Working Paper, p. 935, European Central Bank.

Raczkowski, K. (2015). Dimensions of the Function of Information Provision of Tax Authorities in Management of Public Levies. Economics and Management - Volume 7/Issue 2/ 2015: p. 63-70.

Salo, S. (2013). Optimization of tax loading on the economy as the main direction of tax policy improvement of the country. Journal of Applied Economic Sciences (JAES) (Journal of Applied Economic Sciences (JAES)), issue: 3(25)/2013: p. 353-360.

Schneide,r F., \& Raczkowski, K. (2014). Size and development of the shadow economy and of tax evasion within Poland and of its neighbouring countries from 2003 to 2013: some new facts. The Economic Security of Business Transactions. Management in Business, Chartridge Books Oxford, Oxford 2013: p. 3-31. 
Soliwoda, M., \& Pawlowska-Tyszko, J. (2014). Agricultural taxation in Poland vs. solutions in selected EU countries. Economic Science for Rural Development No. 33, 2014: p. 99-107.

The World Bank and International Finance Corporation. (2014). Paying Taxes 2015: The global picture / PricewaterhouseCoopers' research // - 2014 edition. - W.: - 2014: p. 1-166.

Titov V., \& Gigul'skiy G. (2013). Valuation of influence of tax systems on the effectiveness of industrial enterprise performance. Scientific and technical statements STU. Economic sciences № 4 (175), 2013: p. 113-120.

Zucman, G. (2014). Taxing Across Borders: Tracking Personal Wealth and Corporate Profits, The Journal of Economic Perspectives 28 (4): p. 121-148.

\section{Николай АНДРИЯШ \\ ОПТИМИЗАЦИЯ НАЛОГООБЛОЖЕНИЯ КАК ПРЕДОПРЕДЕЛЯЮЩИЙ ФАКТОР ЭКОНОМИ- ЧЕСКОГО РАЗВИТИЯ (ПРИМЕР ПОЛЬШИ)}

Аннотация. Основная цель работы заключается в сравнении систем налогообложения и налоговой оптимизации в Польше с соответствующими налоговыми процессами в отдельных государствах-членах ЕС, а также изучение их влияния на экономический прогресс в целом. В работе представлена структура, особенности и специфика системы налогообложения в Польше по средством экономического анализа принятых фискальных мер в отдельных странах ЕС. Также обсуждается типология налоговых мер, относящихся к приоритетам налоговой оптимизации в Европе. Методика. Автор использовал первичные и вторичные данные из Центрального статистического управления (ЦСУ), исследований Pricewaterhouse Coopers и Евростата. Методы исследования, используемые для целей анализа данных, содержат экономический анализ правовых актов, описательные части статистики и сравнительного анализа. Результаты показали, что уровень налоговой нагрузки в Польше более умеренный, чем в других развитых странах мира, а механизм администрирования налогов и сборов является гораздо более успешным. Доля поступлений, собранных с помощью децентрализованных административных налоговых органов неуклонно растет, так как фундаментальные основы для этого были заложены еще соответствующими реформами 1999 года и революционным финансовым законодательством, принятым в 2004 году. Исключение некоторых категорий стратегических отраслей промышленного производства из режима частичного налогообложения и включение полученных доходов / прибыли в систему прогрессивного налогообложения является очень верным шагом. Это указывает на практическую реализацию принципов налогообложения Адама Смита, касающихся налоговой справедливости и способности налогоплательщика по уплате обязательных платежей. Практическое значение. Налоговая оптимизация, чтобы сбалансировать уровень налоговой нагрузки, предлагает определенный спектр льгот и преференций, которые стимулировали бы экономику страны и не вызывали бы обострения проблемы перемещения налоговой нагрузки с одного плательщика налога к другому. Многие национальные государства, заметив такое явление как уклонение от уплаты налогов, немедленно начинают осуществлять или намерены реализовать конкретные реформы, которые могли бы помочь улучшить систему налогового контроля с целью создания условий, которые делают уклонение от уплаты налогов и сборов невозможным. Значение/оригинальность. Результаты проведенного исследования являются основой для составления синтетических выводов и выработки налоговых рекомендаций не только для Польши, а также для соседних развивающихся стран. Определение наиболее подходящего фискального курса налоговых реформ правительством в аспекте оптимизации остается интересным научным вопросом для дальнейших исследований. 